\title{
The Roles of Civil Society to Changing of Women Driving Policy In Saudi Arabia: The Case of Women2Drive Campaign
}

\author{
Najamuddin Khairur Rijal
}

Department of International Relations, Universitas Muhammadiyah

Malang Email: najamuddin@umm.ac.id

\section{Rizka Zahrotun Khoirina}

Department of International Relations, Universitas Muhammadiyah Malang rizkazahrotun@gmail.com

\begin{abstract}
This paper examines the role of civil society, women activists, in an attempt to protest the prohibition of women driving policy by the government of Saudi Arabia. Using the concept of civil society, this paper shows that the efforts of women activists are conducted through Women2Drive campaigns by utilizing social media instruments. The results found that through a campaign in social media, Saudi women activists managed to push for a policy change of Saudi Arabian government to allow women driving.
\end{abstract}

Keywords: civil society, Women2Drive campaign, social media, Saudi Arabia Abstrak

Tulisan ini mengkaji mengenai peran civil society, yakni aktivis perempuan, dalam usaha memprotes kebijakan larangan mengemudi bagi perempuan oleh pemerintah Arab Saudi. Dengan menggunakan konsep civil society, tulisan ini menunjukkan bahwa upaya aktivis perempuan tersebut dilakukan melalui kampanye Women2Drive dengan memanfaatkan instrumen media sosial. Hasil kajian ini menemukan melalui kampanye di media sosial, aktivis perempuan Arab Saudi berhasil mendorong perubahan kebijakan pemerintah Arab Saudi untuk mengizinkan perempuan mengemudi kendaraan. 
Kata kunci: civil society, kampanye Women2Drive, media sosial, Arab Saudi

\section{Introduction}

The basic law of the Kingdom Saudi Arabia government based on the Quran (the holy Muslim book) and Sunnah (the prophet Muhammad's saying and activities) both of those basic law underlies the Arab Saudi constitution that rules the citizen lives through the policies. The result, the religious institution has the crucial roles and the widespread influence to set out the policies. Moreover, the religious institutions have the major control of all the affairs concerning Kingdom as well as the exclusive male judiciary and the policing of the public morality. Even though the policies might not be discriminatory on targeting both women and man when assessed for the value, but in reality there is sex segregation in all the workplace, including the women's activities on driving the car alone (Rajkhan and Dana, 2014). The role and the culture in line to become the man as a guardian all the time. This is how the women should be follows not only the religion but also the culture (Quilla, et. al., 2015).
Those many kind of issues opened the discrimination of equality between women and men. The Saudi government does not let the women do their activity as freedom as men included driving. King fatwa who is declared by religious authorities, Muttawah, said that women driving is Haram, forbidden by Islamic law which is written after the Koran. Saudi Arabia is the only country in the world who ban the women to drive. Although, the prohibition law of women driving is not written law, but the licenses in necessary to legally drive. Since women's rights organizations are banned in Saudi Arabia, women have started unofficial groups that are seen as criminal acts almost all the things that they do are seen as a criminal and should be arrested. In 1990, in Riyadh the dozens of women drove car were arrested by religious police. The police confiscated their passports, in spite of it was given back a year later and the consequence they were put under surveillance from then on (Quilla, et. al., 2015).

In 2007, thousand women lead by Wajeha al-Huwaider had a sign 
a petition sent to King Abdullah for their rights to drive. In 2008, she was continuing her protest with declared her campaign, namely "Women2Drive" from a video when she was driving a car, this video protest were posted on YouTube. "Women2Drive" campaign was officially launched in 2011 by Female activists. The Women2Drive campaign used not only Facebook but also through YouTube and Twitter to mobilize support and take a stronger stand against the ban. This paper provides the systematic analysis of the specific roles of civil society in the context of women's rights activist in Saudi launched the Women2Drive campaign as the protest of Saudi policy toward women. Therefore, the aim of this study is to examine Women2driving Campaign Emerged and analysis the efforts of civil society of social media campaigns by Saudi Arabia's Government let the women driving.

The study starts by providing an overview of the concept civil society. It elaborates the civil society concept and practice is analyzed in terms of its civil society roles and functions in case of women's activist in Saudi Arabia who launched campaign Women2Drive using social media as tools. The results demonstrate that the roles of civil society for a very long time, with any kind of protest involves social media as a tool to widely, persuade, mobilized and influence the local and global society to support this campaign. Under the widely campaign, the international managed to control the Arab Saudi government to change the policy and let the women driving and automatically recognized their driver license.

\section{The Concept of Civil Society}

"Civil society" is a complex concept. There is no single definition about it. Generally, civil society is the arena of volunteering, they act due to the same interests, purposes and values are non-controversial (Paffenholz and Spurk, 2006). Bhikhu Parekh (in Glasius, et. al., 2004: 15) explains civil society referred to a group of individuals held together, and forming a single society, by virtue of subscribing to a consensually based public authority and sharing in common the practice of civility. The sociologist Alvin Gouldner characterized civil society as a medium through which people can pursue their own projects in the course of their everyday lives (Layton, 2006: 10).

Civil society is the sector of voluntary action within institutional forms without affiliation with a state, 
political and not driven by economic interest, private sector, interest in public sphere in which civil society reform as the independent organization. In other words, civil society, according to Kaldor definition (in Glasius, 2004: 166), civil society is the process through which individuals negotiate, argue, struggle against or agree with each other and with the centers of political and economic authority.

According to Paffenholz and Spurk (2006: 7-8), from Markel and Lauth (1998), there are five essential functions of civil society, which are: (1) protect the rights of society, (2) intermediation between state and citizens, (3) participatory socialization, (4) community building integration,

(5) communication of agenda or interest where people have room for debate, participation, and democratic decision building with involves non state element through diverse media.

Besides, Edwards (2004 in Paffenholz and Spurk, 2006), elaborated civil society in three roles. First, civil society as associational life. It is the world of voluntary associations that act as for developing values such as tolerance and cooperation. The second, civil society as the good society. Civil society fostering specific positive norms and values, emphasizing that activities must be geared toward specific social and political goals. The third, civil society as the public sphere. The role of civil society is to provide a public sphere where citizens argue with one another about the great questions of the day and negotiate a constantly evolving sense of the common and public interest. It is central for civil society and crucial for democracy to interact fairly in the public sphere.

Regarding these concepts above, we offer a framework concept of analysis used the communication function of civil society. And, the role model of civil society as public sphere which is an area in social life where the people can come and gather together to freely discuss and identify societal problems, and through that discussion influence political action. Through civil society concept, we want to bridge the understanding women's rights activist in Saudi as a civil society which want to speak out for demanding the inequality between women and man within social, economic and politic aspect and recognized the universal value for women and man include the driving policy. So that the women's right activist in Saudi created some 
campaign like Women2Drive with direct protest or more with social media like Facebook, YouTube, and Twitter to pressure the government to revoke the ban women and let the Saudi women drive and give their driver license.

\section{Gender Inequality in Saudi Arabia}

The issue of gender inequality in Saudi Arabia has been discussed widely in recent years. Saudi Arabia has a unique culture of history that did not let the women drive their car without a guardian. Culture, religionbased give the impact of conservative rules and regulations in Saudi that affects in every aspect of the Arans life. Saudi Arabia has developed a reputation for being more restrictive of women's mobility and public activity than other Arab state due to the implementation of Islamic principles there are from the Qur'an and Hadist. However, many of the scholars thought that the restriction by the Saudi Government from women is encouraging the gender inequality. The restriction is also addressing women for a drive, Arab Saudi government are banned women for driving car with or without their guardian. Government does not recognize through Saudi government does not release the driver license for women.
Gender inequality issues have brought in Saudi Arabia, are taking a very limited space for women. However, the western perspective claim that Arab Saudi law who used Islamic law as a principle and guidance are violence the human rights especially the women's rights. The evidence, indeed almost the whole life aspect of women is depending on her guardian involves a father, brother or husband. For example, married women should obedient to their husbands for whatever she wants to do, go out from home, business, hang out with her friends of even go to the women's parent home. But in this case Saudi has their own rules to protect the women, although another perspective or Western perspective claims that Arab does not respect the human rights even they claim that it was violence the women's right. Saudi as a country that has quite strong with sexist or patriarchy, which is this approach took place that men has place beyond women in family, religion, and social. Although, Saudi women have been given the opportunity to vote, worked and et cetera, but the violence in domestic not enough to be handled by government.

Doumato (2005 in Alsaleh, 2012) state that the incidents 
of domestic violence are rarely reported an ad publically, including the women violence incidents. She adds that there are no specific laws of protection on women from the violence and protection for the victim. She found women have less freedom than man, even in the family, their freedom of movement are restricted no exception for their right and opportunities in the economic aspect.

Cosby (2011 in Alsaleh, 2012) states that although Saudi women will be allowed to vote in the 2015 election, but still the Saudi authority significantly limited the mobility could prevent women Saudi from making it to the polls. In the same case with the right of women in elections, the Saudi Arabia's highest religious body defies the women campaign to driving on International Women's Day 2008 due to the fatwa of prohibition of women driving, the authority assumes that it could lead women to mix unrelated men and ultimately bring "social chaos".

About this, Rothna Begum, a researcher Human Rights Watch (HRW) for Middle East and North Africa, said "It is hard to believe that in the $21_{\text {st }}$ century, Saudi Arabia is still barring women from driving. It is past time to address the country's systemic discrimination, driving could open roads to reform" (HRW, 2013). So, HRW as global civil society organization that concern for human rights agenda in the world urged that Saudi authorities should end the country's driving ban for women.

In 2011, Wajeha al-Huwaider as a leader of women's activist in Saudi Arabia lead the Saudi female activist launched the campaign namely "Women2Drive". Wajeha started by uploaded a video of herself while she drives a car in Saudi Arabia. And also the women activist utilizes the massive of social media to the women activist in Saudi to helps them to organize and galvanize momentum in which activist called "women with International driver's licences to take the road on the same day on June 17 .

The effort of women activist did not stop for a short time, but they were really fighting for a long time until they get the name of equality, and Saudi's government let the women to drive. These all kinds of issues of women, inequality, violence, discrimination, etc. the trigger the women's human right activist to speak out of all the kind of women problem. They believe the patriarchal system is just giving the advantage for men to pursue 
their interest of women. So the women's activist to lead by Wajeha al-Huwaider did campaign, protest, until made petitions who sent to King Abdullah for their rights to drive.

\section{The Emerge of "Women2Drive" Campaign}

Following the 1990 protest on women driving banned from the Saudi's highest religious body of women driving based on fatwa and become official policy. In 2009, women's right activist and citizen have made a progress for discussion to campaign the prohibition on women driving. The generate social dialogue on prohibition of women driving among Saudi citizens, taking up the baton from Areej Khan's, a Saudi artist and graphic designer living in the United State who created a low-budget on and offline campaign namely "We the Women" against the fatwa on women driving in Saudi Arabia.

She designed a set of stickers "declaration bubble", she encourages people to print them out and then she distributed the stickers to the public who pasted in the public space or in the Saudi Arabian cars. The supporters of this project were also uploaded their personalized stickers to the project's Flickr set or Facebook page, or email them to the Khan anonymously. Facebook becomes the majorly campaign, become the central point of discussion on the issue of women driving (Begum, 2017).

In 2011, women's rights Saudi activist who lead by Wajeha alHuwaider uploaded the video of herself driving protest in Riyadh as a mark that women's activist Saudi would not give up on the effort that has been made. Saudi female activists launched the "Women2Drive" campaign. The Women2Drive campaign is using, just not Facebook, but also used YouTube and Twitter to mobilize support and take a stronger stand against the ban.

On October 2013, Saudi women's rights activists have called on women with international drivers' licenses to get behind the wheel as part of the "Women2Drive" campaign to end the prohibition on driving. Women activists pushed for another round of driving the protests. They posted videos of themselves driving, including one to the tune of Jon Bon Jovi's "It's My Life," that campaign is also supported by the men who driving through the road with showing their thumbs up. Their campaign got warnings from Saudi authorities 
that they want them to be arrested. But on October 26 women drove in various part of the country without arrests. The ban's justification began to fall away (Begum, 2017).

For many female activists, banned of women driving had become symbolic of the wider discrimination they faced. It is the source of from the guardian laws, the legal codes based on a strict interpretation of shariah laws. The most serious impediment to the Saudi women are the guardian system, a woman needs the permission of a male guardian such as a father, brother, husband, or even a son. Before she can travel outside the country, obtain a passport, study abroad on a government scholarship, get married or exit the prison. The aims of end the discrimination, women Saudi did the campaigned creatively through the tools of social media. In above, we discussed a little about the campaign through social media as official Facebook, YouTube, and Twitter who used by women's rights activist. It is the important to be discussed as the roles of women's activist to against the Saudi Policy the prohibition of women driving.

\section{Campaign through Social Media}

In the globalization era, technology as the main central of the human life. Technology considered is the important tools to help the human work. In the last several years, technology of information and communication are increased along with increasing population in this world, and the impact is improving the media social users. Facebook, YouTube, Twitter and other social media tools to disseminate messages has grown significantly, and continues to trend upward.

Using social media tools has become an effective way to expand reach, foster engagement and increase access to information. Social media and other emerging communication technologies can connect millions of voices to increase the dissemination of the new information, leverage audience networks to facilitate information sharing, expand reach to include broader, more diverse audiences, personalize and reinforce certain messages that can be more easily tailored or targeted to particular audiences, facilitate interactive communication, connection and public engagement (www.cdc.gov, 2011).

Integrating social media into Women2Drive campaigns and activities allows communicators to leverage social dynamics and 
networks to encourage participation, conversation and community, all of which can help spread key messages and influence the decision making. Social media also helps to reach people when, where and how they want to receive messages from the Women2Drive campaign with the purposed to counter the prohibition women driving by the Saudi's Government. A campaign using social media can reach out the widely audience, local and global. Such way could be the effective way to persuade the local and global society to support the women's rights to against Saudi policy about prohibiting women drive through Women2Drive Campaign.

The first, Facebook as the central campaign of \#Women2Drive. Women's activist used Facebook for a long time to promote the gender equality in Saudi Arabia by Women2Drive campaign, which are as the protest to government on the Fatwa and policy that women drive is Haram and the government banned it. By Facebook, they could share and captured of their leave under the discrimination on their roles and position in domestic (family) and public as they could not drive a car or motorcycle or even bicycle, ban women to traveling alone, can not do the same as man does and share it by writing text or make a video and make hashtag \#Women2Drive. Support to accommodate the their hard feeling condemn the inequality in their country as is prohibition women driving policy.

The second, YouTube as the second social media who used Women2Drive campaign. They were sharing their self video when a demonstration of driving a car in Riyadh until they catch by the authorities and going to jail and other kind of video who shows women in equality. By sharing videos on YouTube it can increase awareness the viewer means the global society to support their action and follow pressure the Saudi government to let the women drive and give the driver license.

The Third is Twitter. Not much different from Facebook and YouTube, Women2Drive campaign also using Twitter as a medium to accommodate their messages. These media used for a long time as a campaign to mobilize and influence the global society to support the women's right Saudi movement to pressure the Saudi decision makers to let the women driving and addressing the recognize of giving the driver license to women. However the widely and long campaign influence 
the United State and other state to involve in this issue and supported this campaign by influential even pressured the Saudi government to change the policy toward women driving on the basis of Human Right. Under the pressured of all parties, women's right activist, local female, international society, others country until United Nations, the Saudi Government want to change the policy of banned women driving become women driving allowed.

Below are some picture that represent the demands and struggles of women in Saudi Arabia to fight for the freedom to drive.

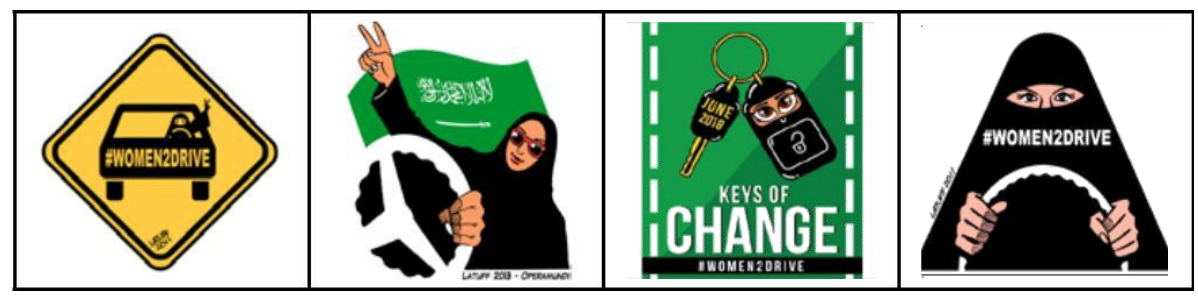

Picture 1. Women2Drive Campaign in Various Media

Sources: ( https://mronline.org, 2011; https://cms-assets.tutsplus. com, 2017; https://blogs.position2.com/imguploads, 2011; https:// latuffcartoons.files.wordpress.com, 2013

\section{Saudi Arabia Government Let} the Women Driving

Pressured of all parties made a great decision on government, Saudi Arabia welcomes praise from human rights advocates over a decision to finally let women in the country drive. On 26 September 2017, the Saudi government announced the abolishment of prohibition of women drive policy that's become the global symbol of the oppression of women in the ultraconservative Kingdom. In a royal decree issued, King Salman announced that women seeking drivers' licenses would be allowed to finally access them. This statement supported by Saudi Arabia's ambassador to the United States Prince Khalid bin Salman bin Abdulaziz, hailed the decision that Arab Saudi leadership understands his society is ready.

The decision highlights, the prohibition of women to drive gave the impact of the damage on the kingdom's international reputation and hopes the reform would give the benefits of public relations. Saudi leaders also hope the new 
policy will help the economy by increasing women's participation in the workplace (Hubbard, 2017). Many working Saudi women spend much of their salaries on drivers or must be driven to work by male relatives.

Saudi women have widely expressed excitement over the change, a cause for which feminists across the country have long been fighting and they have been waiting for a long time. This great decision greeted by Saudi women includes Saudi university professor Fawziah al-Bakr, who participated in a 1990 protest against the female driving ban, in his interview with New York Times she said that it is amazing, publication the moment was a huge victory (Crunden, 2017). However, the policy that allowed women driving does not a mark of totally end of discrimination and inequality in Saudi, policy change just a fraction of effort of women Saudi to gain their equal position in social, economy and politics.

\section{Conclusion}

This study concludes by stating that the government of Saudi Arabia has achieved progress to let the women driving and gave their driver license by pressured from women's rights activist
Saudi though protest, direct demonstration and some campaign included a Women2Drive campaign against toward Saudi policy who banned the women driving. These initiatives are considered to be major advancements for the rights of women in a conservative society such as the Saudi society. With the long way protest women's right activist and women Saudi achieve the great decision for government and they were really excited. These campaigns could not be separated with social media as Facebook, YouTube and Twitter who gave the biggest contribution to accommodate the women's rights activist messages to global. Media considered very helpful to mobilized and influences in the international world.

\section{References}

Alsaleh, S. A. (2012). Gender Inequality in Saudi Arabia: Myth and Reality, Department of Health Informatics, School of Public Health \& Health Informatics King Saud bin Abdulaziz University for Health Sciences Riyadh, Saudi Arabia. Retrieved December 17, 2017, from http://ipedr.com/ vol39/025ICITE2012-K00003. pdf 
Begum, R. (2017). The Brave Female Activists Who Fought to Lift Saudi Arabia's Driving Ban, Retrieved December 27, 2017, from https://www.hrw. org/news/2017/09/29/bravefemale-activists-who-fought lift-saudi-arabias-driving-ban

Coker, Margaret. (2018). How the Guardianship Laws Still Control Saudi Women, Retrieved June, 22, 2018, from https://www. nytimes.com/2018/06/22/ world/middleeast/saudi - womenguardianship.html

Crunden, E. A. (2017). This might be the real motive behind Saudi Arabia's decision to let women drive. Retrieved December 27, 2017, from https://thinkprogress.org/ saudi-arabia-yemen-women98e7e7268a53/

Human Right Watch. (2013). "Saudi Arabia: End Driving Ban for Woman", Retrieved December 29, 2017, from https://www. hrw.org/news/2013/10/24/ saudi-arabia-end-driving-banwomen

Paffenholz, $\mathrm{T}$ and Spurk, C. (2006). "Civil Society, Civic Engagement, and

Peacebuilding". Social Development Paper: Conflict
Prevention and Construction, Paper No. 36/October 2006, Retrieved December 29, 2017, from http://siteresources. worldbank . org/INTCPR/ Resources/WP36_web.pdf

Layton, R. (2006). Order and Anarchy: Civil Society, Social Disorder and War. New York: Cambridge University Press

Office of the Associate Director for Communication. (2011). The Health Communicator's Social Media Toolkit. Retrieved December 28, 2017, from https://www.cdc.gov/ socialmedia/tools/guidelines/ pdf/socialmediatoolkit_bm.pdf Omen Are Set to Defy Prohibition and Drive. Retrieved December 27, 2017, from https://www. hrw.org/news/2013/10/24/ saudi-arabia-end-driving-banwomen

Parekh, B. (2004). "Putting Civil Society in Its Place." In Marlies Glasius, et.al. Exploring Civil Society: Political and Cultural Contexts. New York: Routledge Quilla, A., et. al. (2015). Women Rights Organization in Saudi Arabia and France. Retrieved November 22, 2017, from http://curca . buffalo. edu/ students/pdfs/2015_posters/ 
womens-rights-organizations-

in-saudi-arabia-and-france.pdf

Rajkhan, S. F. and K. Dana. (2014).

Women in Saudi Arabia

Status, Rights, and Limitations,

University of Washington Bothell

School of Interdisciplinary

Arts and Sciences. Retrieved

November 4, 2018, from

https://digital.lib.washington.

edu/researchworks/bitstream/

h a nd le/1773/25576/

Rajkhan\%20-\%20Capstone.

pdf?sequence $=1$ 